\title{
Plasmodiophora brassicae chitin-binding effectors guard and mask spores during infection
}

\author{
Kevin Muirhead ${ }^{1}$ and Edel Pérez-López ${ }^{2,3,4,5 *}$ \\ ${ }^{1}$ University of Calgary, Alberta, Canada \\ ${ }^{2}$ Department of Plant Sciences, FSAA, Université Laval, Québec, Canada, ${ }^{3}$ Centre de recherche et \\ d'innovation sur les végétaux (CRIV), Université Laval, Québec, Canada, ${ }^{4}$ Institut de biologie \\ intégrative et des systèmes (IBIS), Université Laval, Québec, Canada, ${ }^{5}$ Centre de recherche en \\ sciences du végétal (Centre SÈVE), FRQNT, Québec, Canada
}

*Corresponding author: edel.perez-lopez.1@ulaval.ca

Kevin Muirhead: 0000-0002-5742-562X

Edel Pérez López: 0000-0002-3708-8558

\begin{abstract}
Plants have a sophisticated and multilayered immune system. However, plant pathogens, helped by effector proteins, have found several strategies to evade plant immunity. For instance, the clubroot pathogen, Plasmodiophora brassicae, is able to turn the roots of the susceptible hosts into nutrientsink galls surpassing patterns-triggered immunity (PTI) and effector-triggered immunity (ETI). Chitin, the main component of $P$. brassicae spores cell walls and a well-known pathogens-associated molecular pattern (PAMP), can elicit PTI but is also the target of plant chitinases and chitin deacetylases. The fact that $P$. brassicae does not trigger PTI during the infection of the susceptible hosts motivated a genome-wide search of genes coding for secreted chitin-related proteins. We found that $P$. brassicae genome encodes a large repertoire of candidate-secreted effectors containing the chitin-binding domain carbohydrate-binding module family 18 (CBM18), along with chitinases and chitin deacetylases domains. The role of such proteins in the pathogenicity of the clubroot pathogen is unknown. Here, we characterized the function of two effectors, PbChiB2 and PbChiB4, which are transcriptionally activated during the spores transition to uninucleate primary plasmodium and during the spore formation. Through co-precipitation, we found that recombinant $P b C h i B 2$ and $P b C h i B 4$ bind to the spores and to chitin oligomers in vitro. We also showed that both proteins suppress chitintriggered activation of the immune MPK3 and MPK6 in the host Brassica napus. These findings suggest a dual role for the $P$. brassicae CBM18 proteins as effectors for protecting zoospores and resting spores formation and for suppressing chitin-triggered immunity during the infection.
\end{abstract}

Keywords: chitin-binding protein, clubroot, canola, effectors, chitin-triggered immunity

\section{INTRODUCTION}

Pathogen colonization is an essential step of infection extremely guarded by the plant hosts (Zipfel 2014). Through pattern-recognition receptors (PRRs) located on the cell surface, plants can perceive pathogen-associated molecular patterns (PAMPs) and the activation of PRR-triggered immunity (PTI) takes place (Dodds and Rathjen 2010). This first layer of immunity is characterized by the generation of reactive oxygen species, the activation of channels, and the phosphorylation of mitogen-activated protein kinases leading to a wide array of antimicrobial defense mechanisms (Dodds and Rathjen 2010; Zipfel 2014). However, plant pathogens have developed very sophisticated strategies to scape PTI, infect the plant host, and to complete their life cycle (Dodds and Rathjen 2010). 
Among other very well studied PAMPs, chitin [polymer of b-1,4-linked N-acetylglucosamine (GlcNAc)n] has been getting a lot of attention by the MPMI community (Volk et al. 2019; Cheval et al. 2020). Chitin is a major component of fungal cell walls, and it has been shown that during the infection, chitin oligosaccharides resulting from the activity of plant chitinases, are recognized by receptor kinases activating PTI (Sánchez-Vallet et al. 2015). To escape chitin-triggered immunity, fungal pathogens have developed several strategies including the secretion of chitin-binding effectors (van den Burg et al. 2006). These effectors can act, not only capturing free chitin oligosaccharides, but also as a shield to protect the pathogens from plant chitinases (van Esse et al. 2007; Marshall et al. 2011). The chitin-binding domains identified in fungal plant pathogen effectors can be divided into three major groups based on their carbohydrate-binding module (CBM) family: (i) CBM family 14 (CBM14), identified in chitin-binding effectors from Cladosporium fulvim (van den Burg et al. 2006) and Mycosphaerella fijiensis (Stergiopoulos et al. 2010); (ii) CBM family 50 (CBM50), also known as LysM effectors, identified in Cladosporium fulvim (de Jonge et al. 2010), Zymoseptoria tritici (Marshall et al. 2011), Magnaporthe oryzae (Mentlak et al. 2012), Colletotrichum higginsianum (Takahara et al. 2016), and Rhizoctonia solani (Dölfors et al. 2019); and (iii) CBM family 18 (CBM18), identified in Magnaporthe oryzae (Mochizuki et al. 2011) and Verticillium nonalfalfae (Volk et al. 2019). While chitin is predominantly found in cell walls of fungal plant pathogens, it is also the main carbohydrate present in resting spore cell walls of in Plasmodiophora brassicae Woronin, the clubroot pathogen.

Clubroot is a devastating disease affecting cruciferous crops worldwide. It is caused by the obligate parasite, biotrophic, soil-borne, parasitic protist $P$. brassicae (Burki et al. 2010). The life cycle of $P$. brassicae takes place in the roots of the infected host. It is divided in two stages: $(i)$ primary infection, characterized by the encysting of the spores, penetration through the root hairs, and the subsequent formation of the zygote, and (ii) secondary infection, stage of the life cycle characterized by the formation of the secondary plasmodium and finally release back to the soil of the resting spores (Liu et al. 2020). Although P. brassicae secondary infection has drawn the most attention because it leads to the host death, primary infection remains the key step for infection (Pérez-López et al. 2020). During the analysis of $P$. brassicae transcriptome in different hosts and developmental stages, several proteins with the chitin-binding (CBM18) domain were enriched in P. brassicae secretome (Schwelm et al. 2015), although the function of these proteins remains unknown. Similar results were obtained in another study looking into effector proteins involved in P. brassicae primary infection (Chen et al. 2019).

Here we performed a genome-wide search to identify all the chitin-related proteins putatively secreted by $P$. brassicae with special focus on those bearing CBM18 domains. Among the proteins identified, we characterized $P b C h i B 2$ and $P b C h i B 4$ which have two CBM18 modules and a functional signal peptide. Both are presumably secreted during resting spores development to plasmodium and during resting spores formation. We show that both proteins bind resting spores and chitin in vitro and that these proteins are able to inhibit chitin-triggered immunity 'guarding' the resting spores throughout the infection.

\section{MATERIALS AND METHODS \\ Plant material and growth conditions}

Arabidopsis thaliana Col-0 and rapeseed (B. napus, canola in Canada) Westar seeds, disinfected with $70 \%$ ethanol, 95\% ethanol, 8\% bleach and sterile water, were sown on 1/2 Murashige and Skoog (MS) salts agar $(1 \%, \mathrm{w} / \mathrm{v})$ plates (Sigma-Aldrich, CAD) with $1 \%$ sucrose. Plates were placed at $4{ }^{\circ} \mathrm{C}$ for 4 
days and then transferred to a growth chamber (Conviron ATC10, CMP4030 control system; $170 \mu \mathrm{mol}$ photons $\mathrm{m}^{2} \mathrm{~s}^{-1} ; 16 \mathrm{~h} / 8 \mathrm{~h}$ light/dark cycle; $20^{\circ} \mathrm{C}$ ) for germination and growth.

\section{Clubroot infection}

Ten-day old Arabidopsis seedlings were transferred to Vèrada soil mix (Farad, CAD) with four plants in each 'square pot' $(3.5 \times 3.5$ inch). Seedlings were allowed to acclimatise in these pots for four additional days before $500 \mathrm{uL}$ of $5 \times 10^{7}$ resting spores $\mathrm{mL}^{-1}$, extracted from canola galls (Pérez-López et al. 2020) was applied to each plant where the stem entered the soil. Control plants were inoculated with $500 \mu \mathrm{L}$ of distilled water (mock inoculation) and grown in separate trays in the same growth chamber.

\section{Bioinformatics analyses}

To identify putative secreted chitin-related proteins we performed a genome-wide search for proteins having a signal peptide prediction score $\geq 0.7$, and a length of $<500$ amino acids in the $P$. brassicae Pbe3.h15 genome (Schwelm et al. 2015). The resulting proteins were analyzed using Pfam (https://pfam.xfam.org/) to identify chitin-related Carbohydrate-Active enZymes (chitin-CAZymes). The proteins identified were characterized using several online tools as previously described (PérezLópez et al. 2020), including ApoplastP (Sperschneider et al. 2017) to know their putative apoplastic localization. The expression of the genes coding these proteins was analyzed using the RNAseq data previously generated by (Schwelm et al. 2015) under the SRA accession numbers ERX1409397 ERX1409403. RNAseq libraries were downloaded using the fastq-dump program of the NCBI SRA Toolkit $\mathrm{v}$ 2.9.6 (Leinonen et al. 2011). The RNAseq libraries were assessed for quality using fastqc $\mathrm{v}$ 0.11.8 (Andrews 2010) and TruSeq3 Illumina adapters were determined from the most represented sequences. Reads were quality-filtered and trimmed using trimmomatic v 0.39 (Bolger et al. 2014) with the following parameter settings ILLUMINACLIP:TruSeq3-PE.fa:2:30:10:2:keepBothReads LEADING:3 TRAILING:3 MINLEN:36. Reads were mapped to the P. brassicae Pbe3.h15 genome (Schwelm et al. 2015) using STAR v 2.7.5c (Dobin et al. 2013). The STAR genome database was generated using the following parameter settings --genomeSAindexNbases 11 --runMode genomeGenerate. STAR was executed using the following parameter settings --runMode alignReads -outSAMtype SAM --outSAMattributes All --outSAMstrandField intronMotif. The SAM output files from STAR were processed using samtools v 1.9 and analyzed using the cuffdiff program of Cufflinks v2.1.1 (Trapnell et al. 2010). The heatmap was generated using cummeRbund 3.12 (Goff et al. 2020) package using the output generated by the cuffdiff program and gene ids shown in Table 1 . The phylogenetic analysis of chitin-CAZymes was carried out using MUSCLE v3 (Edgar 2004) and MEGA v6 (Tamura et al. 2013). The phylogenetic tree was constructed using maximum-likelihood, the JamesTaylor-Thorthon model and a bootstrap value of 1000 .

\section{Signal peptide validation assay}

To validate $P b C h i B 1, P b C h i B 2$, and $P b C h i B 4$ signal peptide (22, 22, and 17 aa, respectively), the 66, 66 and $51 \mathrm{bp}$ fragments were amplified by PCR using as template the cDNA obtained from infected Arabidopsis plants with designated primer pairs introducing EcoRI at the N-terminal and XhoI (NEB, $\mathrm{CAD}$ ) at the C-terminal end (Table S1). The amplified signal peptide fragments were introduced into the plasmid pSUC2 (Prof. Sophien Kamoun, The Sainsbury Laboratory) using T4 DNA ligase (Promega, USA). The yeast invertase assay was used to validate the signal peptides (Jacobs et al. 1997), following the protocol as previously described (Pérez-López et al. 2020), using the Saccharomyces cerevisiae yeast strain YTK12 (Dr. Hossein Borhan, AAFC-Saskatoon Research Centre). After 
selection in CMD-W media, we analyzed the invertase enzymatic activity as previously described (Yu et al. 2019).

\section{Gene expression analysis}

Total RNA was extracted (Chomczynski and Mackey 1995) from infected plants at 0, 2, 5, 7, 14, 21 and 28 days post inoculation (dpi) and $2 \mu \mathrm{g}$ was used to synthesize cDNA using the QuantiTect ${ }^{\circledR}$ Reverse Transcription Kit (Qiagen, CAD) following the manufacturer's recommendations. Real-time qPCR was performed using $\mathrm{iQ}^{\mathrm{TM}}$ SYBR ${ }^{\circledR}$ Green Supermix (Bio-Rad, CAD) in a $20 \mu \mathrm{L}$ final volume containing $300 \mathrm{nM}$ of each primer and $2 \mu \mathrm{L}$ of cDNA diluted 1:5 (v:v) in RNase-free water. Amplification was carried out using a magnetic induction cycler Real-Time System (Bio molecular systems, AUS), and reactions were quantified using micPCR software (v2.10.0). Each amplification used three technical replicates, results that were averaged to give the value for a single biological replicate. Results are expressed as LOG2 expression relative to P. brassicae ELONGATION FACTORLIKE (PBRA_001540) and A. thaliana ACTIN2 (At3g18780) expression using the comparative quantification method as previously described (Warton et al. 2004). Primers used are presented in Table S1.

\section{Production of recombinant proteins}

For protein expression, the cDNA for PbChiB2 (Fig. S1) and PbChiB4 (Fig. S1) without the signal peptide was synthesized and cloned into plasmid pET-14b (GenScript, USA). Plasmids were used to transform E. coli SHuffle T7 cells (NEB, CAD). E. coli transformants were grown in $50 \mathrm{~mL}$ LB medium supplemented with ampicillin $\left(100 \mu \mathrm{g} \mathrm{mL} \mathrm{L}^{-1}\right)$ at $37^{\circ} \mathrm{C}, 200 \mathrm{rpm}$ for $3 \mathrm{~h}$. Protein expression was induced by the addition of $1 \mathrm{mM}$ IPTG and growth was continued at $37{ }^{\circ} \mathrm{C}, 200 \mathrm{rpm}$ for $2 \mathrm{~h}$. After centrifugation at $3200 \mathrm{~g}$ for $15 \mathrm{~min}$, cell pellets were lysed using a Branson sonicator equipped with a microtip (Branson ultrasonics, USA). Pellets containing His- $P b C h i B 2$, and His- $P b C h i B 4$ were purified with Ni-NTA agarose (Thermo Fisher Scientific, CAD) through native conditions following the manufacturer's recommendations. Protein concentration was measured using a Qubit protein assay kit (Thermo Fisher Scientific, CAD).

\section{Western blot analysis}

Proteins were separated by $15 \%$ SDS-PAGE and transferred to $0.2 \mu \mathrm{m}$ PVDF membranes (Bio-Rad, $\mathrm{CAD}$ ) for $1 \mathrm{~h}$ at $0.4 \mathrm{~V} \mathrm{~cm}^{-1}$ in a Mini-PROTEAN $\AA$ Tetra Cell (Bio-Rad, CAD). His-tagged proteins were detected using monoclonal anti-polyHis-HRP conjugate (Sigma-Aldrich, CAD). Phosphorylated mitogen-activated protein kinases (MAPK) were detected using phospho-p44/p42 MAPK primary antibody (Cell Signally Technology, Leiden, Netherland), followed by a goat anti-rabbit secondary antibody HRP conjugate (Sigma-Aldrich, CAD) following the manufacturer's recommendations. Membranes were blocked with 5\% skim-milk and HPR activity was detected using SuperSignal ${ }^{\mathrm{TM}}$ West Pico PLUS Chemiluminescent Substrate (Thermo Fisher Scientific, CAD) with an Azure imager C300 (Azure Biosystems, CAD), to detect the chemiluminiscent signal.

\section{Carbohydrate sedimentation assay}

This assay was performed as described by Volk et al. (2019). Briefly, $20 \mu \mathrm{g}$ of recombinant $P b C h i B 2$ and $\mathrm{PbChiB} 4$ resuspended in $20 \mathrm{mM}$ Tris ( $\mathrm{pH} \mathrm{8.0)}$ were independently mixed with $2 \mathrm{mg}$ of chitin magnetic beads (NEB, CAD), chitin from shrimp shell (Sigma-Aldrich, CAD), chitosan from shrimp shells (Sigma-Aldrich, CAD), cellulose (Sigma-Aldrich, CAD), or xylan (Thermo Fisher Scientific, $\mathrm{CAD}$ ) and incubated at room temperature for $2 \mathrm{~h}$ with shaking at $300 \mathrm{rpm}$. After centrifuging 5 minutes at $13,000 \times \mathrm{g}$, the supernatant was precipitated with cold acetone and resuspended in $40 \mu \mathrm{l}$ of $2 \times$ SDS- 
PAGE buffer. The pellet was washed with $800 \mu \mathrm{L}$ of $20 \mathrm{mM}$ Tris $\mathrm{pH} 8.0$ and resuspended in $40 \mu \mathrm{l}$ Laemmli sample buffer with $13 \% \beta$-mercaptoethanol. The presence of $\mathrm{PbChiB} 2$ and $\mathrm{PbChiB} 4$ was detected using western blot as described above.

A similar protocol was followed to study the ability of $P b C h i B 2$ and $P b C h i B 4$ to bind resting spores. Each recombinant protein $(20 \mu \mathrm{g})$ was incubated with $1 \times 10^{15}$ resting spores $\mathrm{mL}^{-1}$ extracted from canola galls. In parallel, xylem sap from canola clubs at $21 \mathrm{dpi}$, extracted as previously described (Kehr et al. 2005), was used to study the effect of chitinases on the interaction of $\mathrm{PbChiBs}$ with resting spores. For that, we incubated the proteins with spores preincubated with xylem sap, but also we added the xylem sap to spores preincubated with the recombinant proteins. After each treatment, the spores were pelleted, washed with $20 \mathrm{mM}$ Tris $\mathrm{pH} 8.0$, and the presence of PbChiB2 and PbChiB4 was analyzed as described above. All the sedimentation assays were repeated twice with identical results.

\section{MAPK activation assay}

Brassica napus cultivar Westar was grown for 2 weeks in 1/2-MS liquid medium after germination and seedlings were incubated independently with (i) water (mock), (ii) $1 \mu \mathrm{M}$ chitin [(GlcNAc)6] (Santa Cruz Biotechnology, USA), (iii) chitin pre-incubated with recombinant $P b C h i B 2$ or $P b C h i B 4(10 \mu \mathrm{M})$ for $1 \mathrm{~h}$ at room temperature, and (iv) PbChiB2 or PbChiB4 (10 $\mu \mathrm{M})$ (Fig. S2). Phosphorylated MAPK3 and MAPK6 were detected as previously described (Tsuda et al. 2009) after 4 minutes of treating the seedlings. This was repeated twice with the same results.

\section{RESULTS}

\section{Chitin-related $P$. brassicae CAZymes secreted repertoire}

Sixteen chitin-CAZymes were identified in $P$. brassicae genome under the parameters used in this study (Table 1, Fig. 1A). These proteins were divided into four main categories: chitinases ( $P b C h i)$, chitin-binding $(\mathrm{PbChiB})$, chitin deacetylases $(\mathrm{PbChiD})$, and chitin-binding domains (PbChiBD). An additional candidate with a chitin-binding domain $(P b C h i B T)$, tyrosinase, was also found.

The domain present in the $P b C h i$ proteins was identified as a glycosil hydrolase, family 18 (GH18). The three $\mathrm{PbChi}$ proteins belong to the GH18 cluster A as previously reported (Schwelm et al. 2015). These proteins have less than 500 aa, a predicted signal peptide, and no transmembrane domain (Table 1). The nine $P b C h i D$ and $P b C h i B D$ were identified as members of the carbohydrate esterase family 4 (CE4) family. This family of esterases catalyze the de-acylation of polysaccharides and in all the proteins a NodB-like domain, characteristic of this family, was identified in all nine proteins (Fig. 1A). Proteins of this family have been identified as chitin deacetylases. These nine proteins have a signal peptide and four were identified as putative apoplastic proteins (Table 1). In six of the nine proteins, in addition to the NodB-like domain, we also found a chitin-binding domain (PbChiBDs) (Table 1), the carbohydrate-binding module family 18 (CBM18), with five proteins containing two copies of the domain (PbChiBD1- PbChiBD4, PbChiBD6) and PbChiBD5 with only one (Fig. 1A). Another proteins with the CBM18 domain was a tyrosinase (PbChiBT1) (Fig. 1A, Table 1).

The last four chitin-related $P$. brassicae proteins detected in this study were proteins with only the CBM18 domain ( $P b C h i B s)$ (Asenio et al. 2000) (Fig. 1, Table 1). PbChiB1, with only one module of the CBM18 domain, while $P b C h i B 2$, and $P b C h i B 4$ have two, and $P b C h i B 3$ have two three modules of the CBM18 domain (Fig. 1A). Interestingly, $\mathrm{PbChiBs}$ with one and two modules of the CBM18 domain are predicted to be apoplastic, a common feature of chitin-binding effectors (Volk et al. 2019) (Table 1), while PbChiB3 do not seems to be apoplastic (Table 1). 
Table 1. Description and identity of the putative secreted chitin-CAZymes reported in this study.

\begin{tabular}{|c|c|c|c|c|c|c|c|c|}
\hline Name & Gene ID & $\begin{array}{l}\text { Accession } \\
\text { number }\end{array}$ & $\begin{array}{l}\text { No } \\
\text { aa }\end{array}$ & $\begin{array}{l}\text { MW } \\
\text { (kDa) }\end{array}$ & PI & $\begin{array}{c}\text { SP } \\
\text { cleaveage }\end{array}$ & $\begin{array}{c}\text { TM } \\
\text { domain } \\
\text { (Y/N) }\end{array}$ & $\begin{array}{c}\text { Apoplastic } \\
\text { [Y/N (score)] }\end{array}$ \\
\hline PbChil & PBRA_005464 & CEO96860 & 477 & 50.3 & 4.9 & $21-22$ & $\mathrm{~N}$ & $\mathrm{Y}(0.8)$ \\
\hline PbChi2 & PBRA_005765 & CEO97161 & 357 & 37.9 & 6.3 & $18-19$ & $\mathrm{~N}$ & $Y(0.63)$ \\
\hline PbChi3 & PBRA_003743 & CEO94930 & 400 & 44.3 & 5.8 & $23-24$ & $\mathrm{~N}$ & $\mathrm{~N}(0.66)$ \\
\hline PbChiB1 & PBRA_003759 & CEO94946 & 222 & 22.9 & 7.6 & $22-23$ & $\mathrm{~N}$ & $Y(0.72)$ \\
\hline PbChiB2 & PBRA_001907 & CEP01301 & 137 & 14.4 & 5.3 & $22-23$ & $\mathrm{~N}$ & $Y(0.77)$ \\
\hline PbChiB3 & PBRA_002543 & CEP02278 & 336 & 35.5 & 7.7 & $20-21$ & $\mathrm{~N}$ & $\mathrm{~N}(0.54)$ \\
\hline PbChiB4 & PBRA_002958 & CEP03198 & 172 & 17.9 & 4.2 & $17-18$ & $\mathrm{~N}$ & $Y(0.81)$ \\
\hline PbChiD1 & PBRA_007091 & CEO98977 & 314 & 34.1 & 6.7 & $21-22$ & $\mathrm{~N}$ & $\mathrm{~N}(0.54)$ \\
\hline PbChiD2 & PBRA_002230 & CEP01965 & 263 & 29.6 & 5.6 & $18-19$ & $\mathrm{~N}$ & $\mathrm{~N}(0.71)$ \\
\hline PbChiD3 & PBRA_008962 & CEP02378 & 328 & 35.3 & 4.5 & $21-22$ & $\mathrm{~N}$ & $\mathrm{~N}(0.59)$ \\
\hline PbChiBD1 & PBRA_003161 & CEP03401 & 387 & 40.8 & 4.8 & $29-30$ & $\mathrm{~N}$ & $Y(0.84)$ \\
\hline PbChiBD2 & PBRA_005081 & CEO96410 & 372 & 40.3 & 4.7 & $18-19$ & $\mathrm{~N}$ & $Y(0.59)$ \\
\hline PbChiBD3 & PBRA_002551 & СЕР02584 & 355 & 37.7 & 4.2 & $21-22$ & $\mathrm{~N}$ & $Y(0.8)$ \\
\hline PbChiBD4 & PBRA_007776 & CEP00042 & 402 & 43.5 & 6.8 & $18-19$ & $\mathrm{~N}$ & $\mathrm{~N}(0.61)$ \\
\hline PbChiBD5 & PBRA_001295 & CEO99389 & 302 & 32.3 & 4.9 & $32-33$ & $\mathrm{~N}$ & $Y(0.91)$ \\
\hline PbChiBD6 & PBRA_008942 & СЕР02358 & 367 & 39 & 4.9 & $20-21$ & $\mathrm{~N}$ & $Y(0.77)$ \\
\hline PbChiBT1 & PBRA_004239 & CEO95513 & 440 & 48.9 & 8.6 & $21-22$ & $\mathrm{~N}$ & $\mathrm{~N}(0.73)$ \\
\hline
\end{tabular}
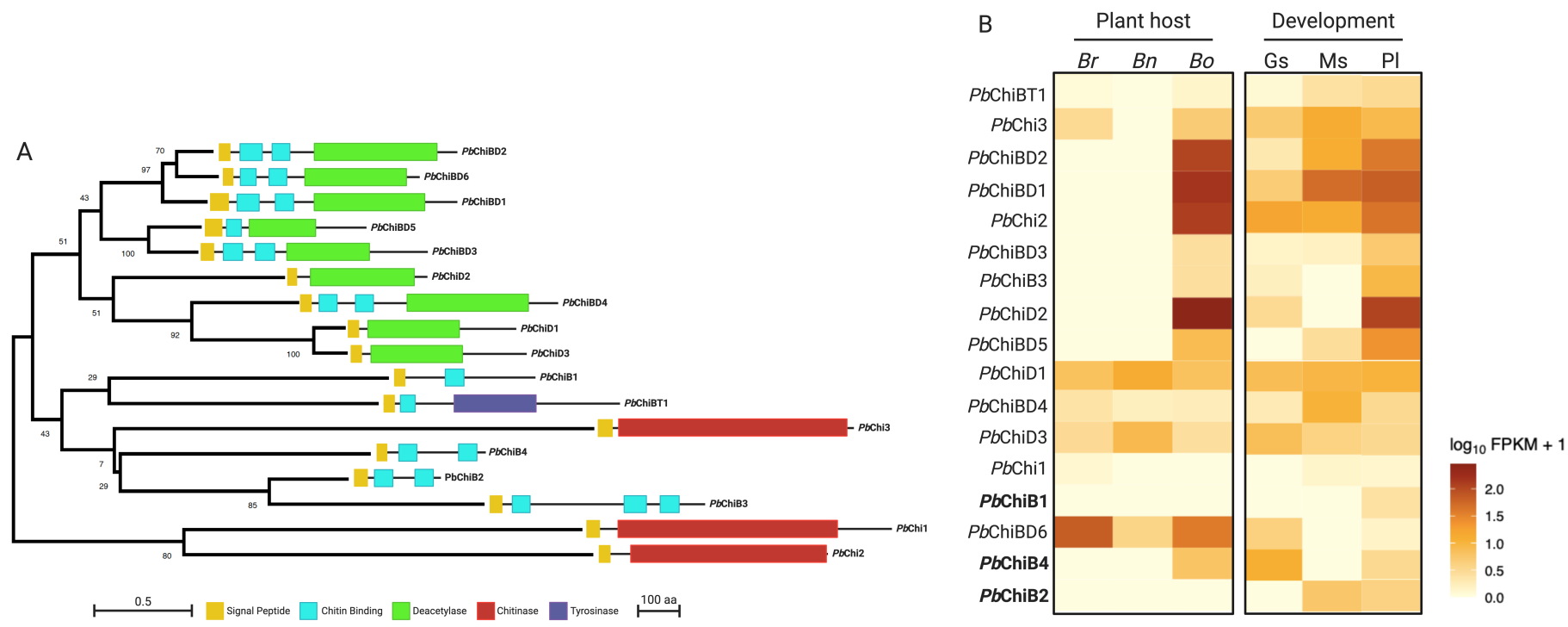

Fig. 1. Phylogeny, structure and expression of Plasmodiophora brassicae chitin-CAZymes reported in this study. A. Phylogeny of the amino acid sequence of the chitin-CAZymes reported here through the using maximum-likelihood tree with MEGA6. The protein domain organization is on the right side of the tree. B. Expression profile of chitin-CAZymes measured using RNA sequencing from Schwelm et al. (2015). Overexpressed (dark orange) or underexpressed transcripts (light yellow) are presented as $\log$ FPKM+1 fold-changes relative to the mean expression measured for three P. brassicae hosts: $B$. rapa $(\mathrm{Br})$, B. napus $(\mathrm{Bn})$, and B. oleracea var. capitate $(\mathrm{Bo})$ during secondary infection (35 dpi), and 
life-stage specific RNAseq data generated from germinating resting spores (Gs), maturing resting spores (Ms) and plasmodia (Pl). RNAseq data analysis scripts and output data can be found at https:/github.com/kevmu/RNAseqDataSchwelm2015. Created with BioRender.com.

\section{Chitin-related -encoding genes are differentially expressed in planta}

To study the expression of the chitin-CAZymes and the chitin-binding proteins we used RNAseq data obtained from $P$. brassicae infected B. rapa, B. napus, and B. oleracea var. capitata during secondary infection (35 dpi), and life-stage specific RNAseq data generated from germinating resting spores, maturing resting spores and plasmodia (Schwelm et al. 2015) (Fig. 1B). In general, we observed a differential expression for each gene based on host and life-stage. Transcripts of seven of the proteins were in the same range in $B$. rapa and B. napus (Fig. 1B), while only one presented the same transcription profile in the three hosts $(P b C h i B 2)$ (Fig. 1B). The remaining ten proteins showed a differential transcription for each host analyzed and for each life-stage. It was interesting to find that the transcript of proteins like $\mathrm{PbChiB} 4$ was preferentially detected in germinating spores and plasmodia but not in maturing spores (Fig. 1B), while the transcripts of other proteins like $\mathrm{PbChiB} 2$ were mostly detected in maturing spores and plasmodia but not in germinating spores (Fig. 1B).

\section{PbChiB proteins have a functional signal peptide}

Moving forward, we focused on $\mathrm{PbChiBs}$ proteins with one and two modules of the CBM18 domain: $P b C h i B 1, P b C h i B 2$, and $P b C h i B 4$, in order to study their role and activity in $P$. brassicae pathogenicity. The first step was to confirm that these proteins have a functional signal peptide, indicating that they might be secreted to the apoplast. For that, the secretory activity directed by $P b C h i B 1, P b C h i B 2$, and $P b C h i B 4$ signal peptides was tested individually. The three signal peptides showed secretory activity in yeast as shown on CMD-W plates, and by the reduction of 2,3,5triphenyltetrazolium chloride (TTC) to insoluble red-colored 1,3,5-triphenylformazan (TPF) (Fig. 2).

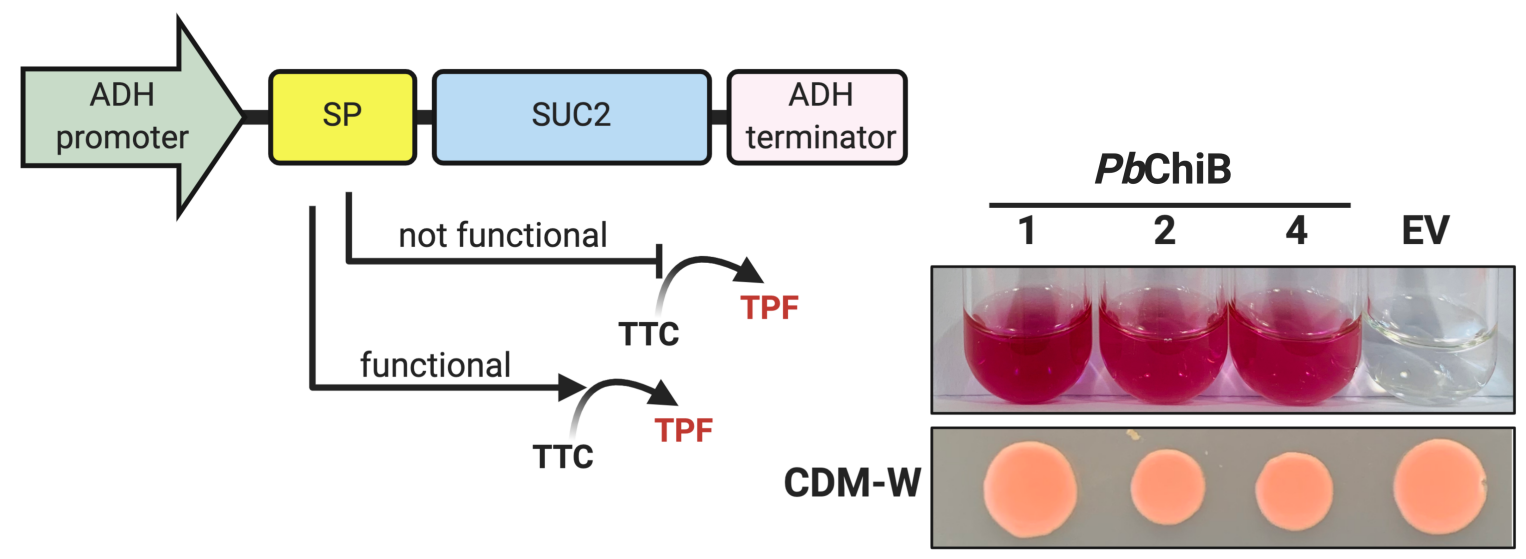

Fig. 2. Functional analysis of $P b C h i B 1, P b C h i B 2$, and $P b C h i B 4$ signal peptide through yeast invertase assay. Schematic representation of the constructs containing the signal peptide sequence of $P b C h i B$ proteins and empty vector (EV) pSUC2 in yeast YTK12 were plated on CMD-W (Trp depleted), and the enzymatic activity of secreted invertase was determined using the reduction of TTC to the redcolored formazan assay. Images are representative of three replicates using independent biological samples. Created with BioRender.com. 


\section{$P b C h i B 2$ and $P b C h i B 4$ bind chitin in vitro}

After analyzing the chitin-binding domain present in the three $P b C h i B$ proteins, we noticed that one of the glycine of the consensus sequence was substituted by alanine in both $P b C h i B 4$ CBM18 $\beta$-hairpin loops (Fig. S3). In $P b C h i B 1$ and $P b C h i B 2$ CBM1 8 domains, we observed the insertion of an alanine and leucine, respectively in the consensus sequence (Fig. S3). In none of the proteins the fourth disulfide bond of the expected conserved four-disulfide core was present (Fig. S3). Based on this analysis and the fact that $\mathrm{PbChiB} 1$ has only one CBM18 module and weak transcripts in the three hosts analyzed and the different life-stages (Fig. 1B), only $\mathrm{PbChiB} 2$ and $\mathrm{PbChiB} 4$ were retained for further analyses (Fig. 3A).

To study the interaction with carbohydrates, recombinant and purified $\mathrm{PbChiB} 2$ and $\mathrm{PbChiB} 4$ (Fig. 3B), were used in a sedimentation assay with an array of carbohydrates. Both proteins were able to bind to chitin immobilized in magnetic beads and shrimp shell chitin, but not to shrimp shell chitosan or to the plant cell wall cellulose or xylan (Fig. 3C). Curiously, although we did not study the affinity of the interactions, we were able to detect in the pellet and the supernatant $P b C h i B 4$ while $P b C h i B 2$ was only detected in the pellet, pointing to a difference in affinity between the proteins (Fig. 3C).
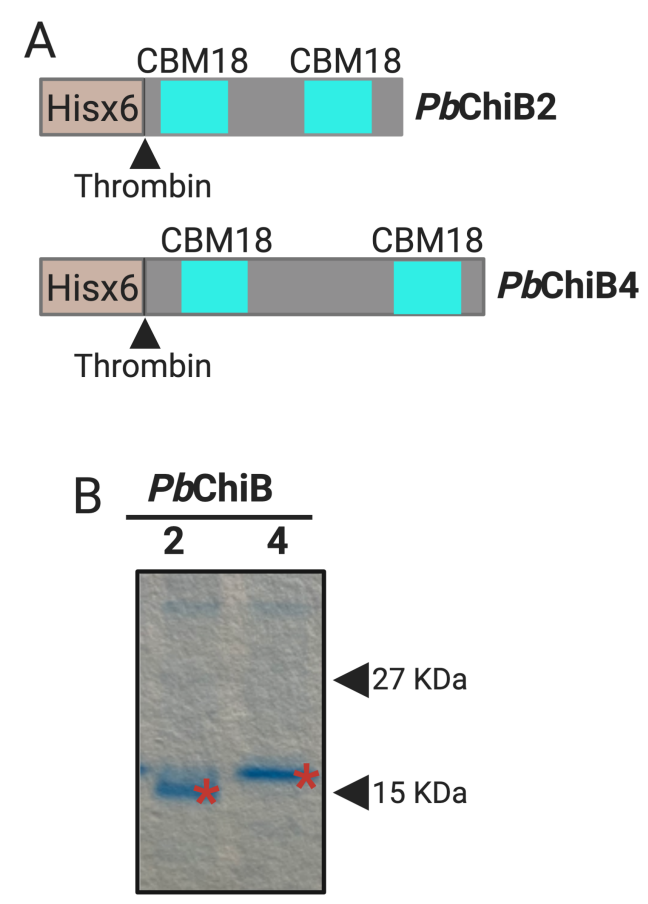

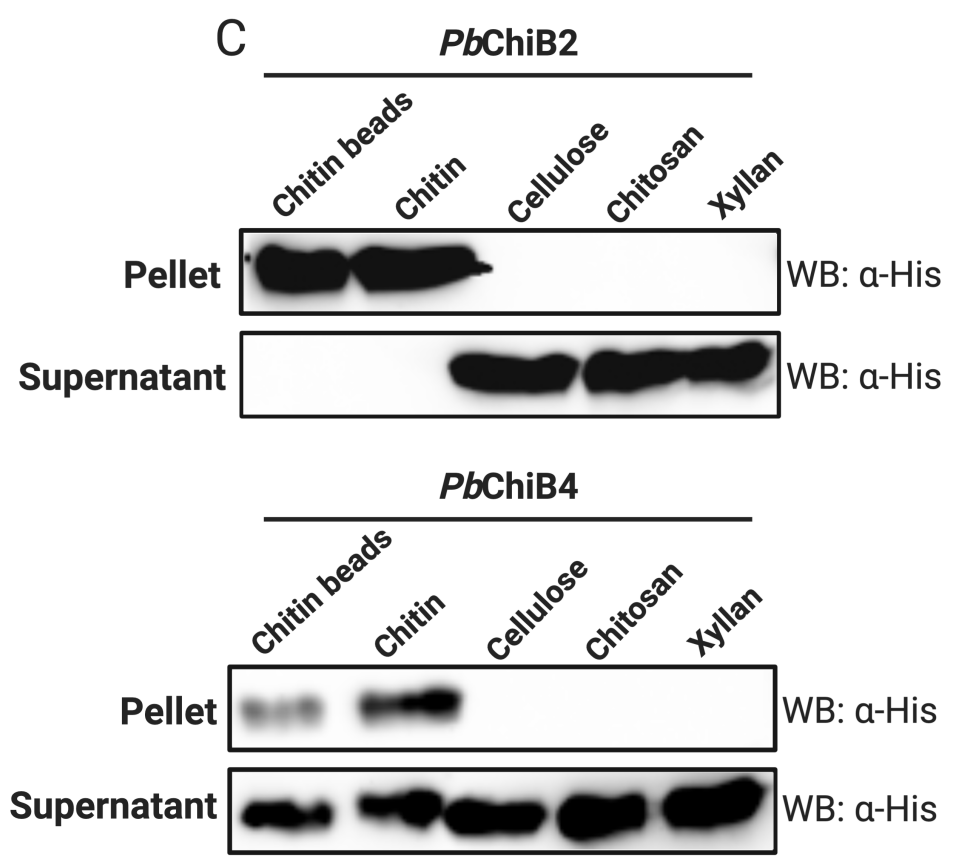

Fig. 3. Plasmodiophora brassicae $\mathrm{PbChB} 2$ and $P b C h B 4$ bind specifically to chitin and chitin oligomers. A. Scheme of the recombinant $P b C h B 2$ and $P b C h B 4$. B. SDS-PAGE 15\% electrophoresis of the recombinant and purified $\mathrm{PbChB} 2$ and $\mathrm{PbChB} 4$ (red star) . C. Affinity precipitation of $\mathrm{PbChB} 2$ and $\mathrm{PbChB} 4$ in the presence of: chitin beads, shrimp shell chitin, shrimp shell chitosan, cellulose and xylan. The supernatant $(\mathrm{S})$ and the pellet $(\mathrm{P})$ samples were analysed after centrifugation. $\mathrm{PbChB} 2$ and $\mathrm{PbChB} 4$ was detected in the pellet fraction of chitin only using anti-His tag western blot. Created with BioRender.com.

\section{$P b C h i B 2$ and $P b C h i B 4$ are preferentially transcribed during resting spore formation}

Although the transcription profile of $P b C h i B 2$ and $P b C h i B 4$ during the infection has been described (Fig. 1B), the primary infection and secondary infection consist in many different steps from 0 to 28 
dpi (Liu et al. 2020). To have a better understanding of the role of these proteins, we studied their expression at four time points of primary infection $(0,2,5$, and $7 \mathrm{dpi})$, and three time points of secondary infection (14, 21, and 28 dpi) using RT-qPCR (Fig. 4A). The expression of both was initiated at $21 \mathrm{dpi}$, with a stronger induction for $P b C h i B 2$ (Fig. 4A). In addition, PbChiB4 was also strongly induced at 2dpi (Fig. 4A). Strikingly, both were strongly induced during the transition from resting sporangial plasmodium to resting spore formation (Fig. 4B), while $\mathrm{PbChiB} 4$ was also highly induced around primary plasmodium formation early after resting spore penetration (Fig. 4B).

\section{$P b C h i B 2$ and $P b C h i B 4$ bind resting spores in vitro}

To study the interaction with resting spores, recombinant $P b C h i B 2$ and $P b C h i B 4$ were used in a sedimentation assay. When $\mathrm{PbChiB} 2$ and $\mathrm{PbChiB} 4$ were incubated with resting spores isolated from canola clubroot galls, we were able to detect the His-tagged proteins in the pellet (Fig. 4C). Similar results, albeit less intense, were obtained with xylem sap from canola clubroot galls (Fig. 4C). Curiously, the interaction was abolished when the resting spores were first pre-incubated with the xylem sap before addition of the recombinant proteins (Fig. 4C).
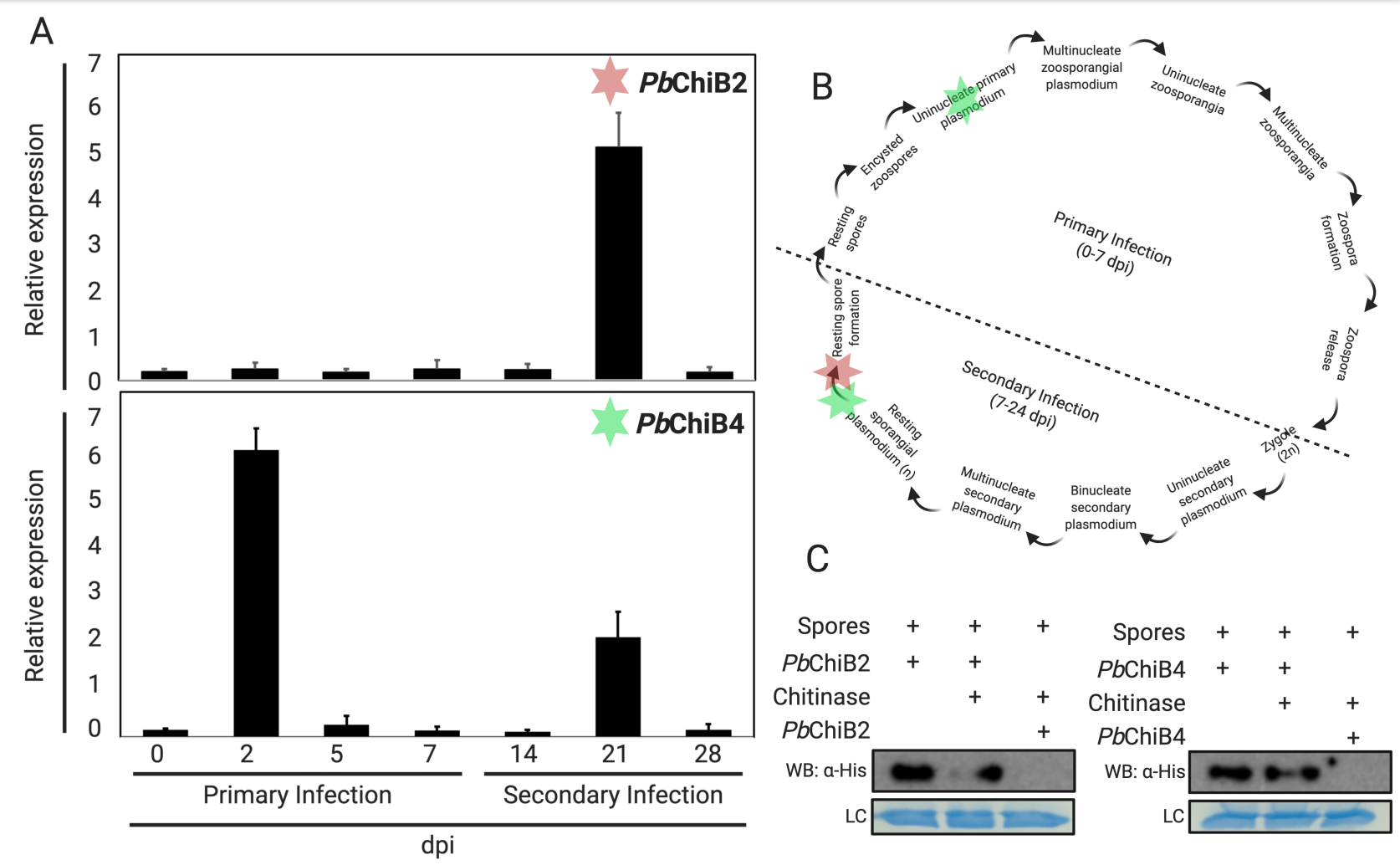

Fig. 4. Plasmodiophora brassicae $\mathrm{PbChB} 2$ and $P b C h B 4$ expression profile and binding to resting spores. A. Expression profiling of $\mathrm{PbChB} 2$ and $P b C h B 4$ genes using RT-qPCR and expression levels are shown relative to the mean expression of relative to P. brassicae ELONGATION FACTOR-LIKE and $A$. thaliana ACTIN2. B. Representation of P. brassicae life cycle based on Liu et al. (2020) marking where $\mathrm{PbChB} 2$ and $\mathrm{PbChB} 4$ were overexpressed. C. Affinity precipitation of $\mathrm{PbChB} 2$ and $P b C h B 4$ in the presence of $P$. brassicae resting spores. The affinity was abolished when the spores were pre-incubated with xylem sap of clubroot galls (represented in the figures as Chitinases). LC loading control. Created with BioRender.com. 


\section{$P b C h i B 2$ and $P b C h i B 4$ suppress chitin-binding immunity}

To study if $P b C h i B 2$ and $P b C h i B 4$ were able to compete with plant chitin receptors and interfere with early chitin-triggered immunity, we treated B. napus seedlings with $1 \mu \mathrm{M}$ chitin [(GlcNAc)6] and registered the activation of MAPK3 and MAPK6 4 min after application (Fig. 5A). When PbChiB2 and $\mathrm{PbChiB} 4$ were pre-incubated with chitin, MAPK activation was clearly reduced in the former, and to a in a lesser extent in the latter (Fig. 5B). The results obtained with $\mathrm{PbChiB} 4$ are in agreement with what we observed during the sedimentation assay. After treatment with water or with the $P b C h i B$ proteins alone did not induce detectable MAPK activation (Fig. 5B).
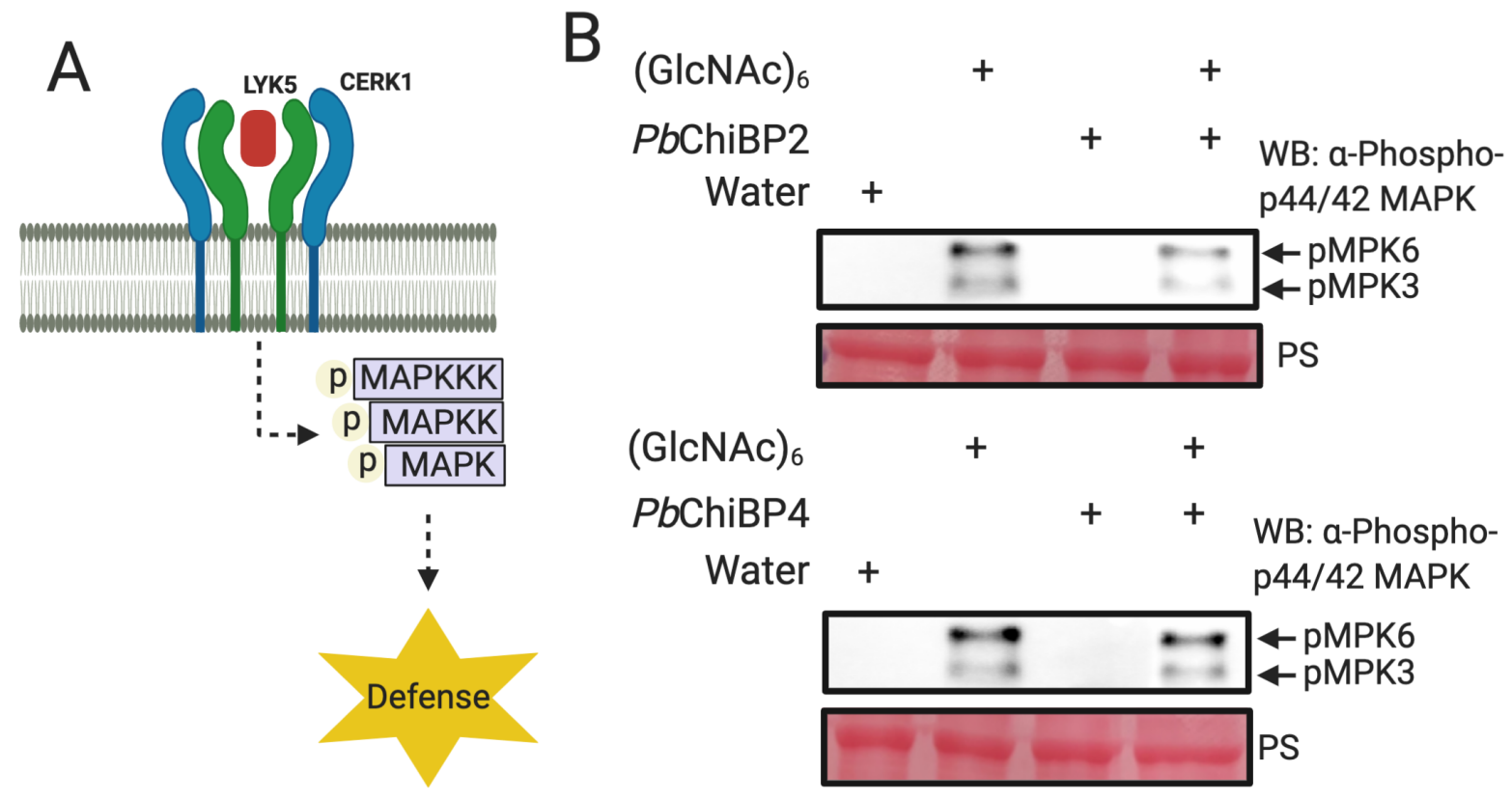

Fig. 5. Plasmodiophora brassicae PbChB2 suppress chitin-induced activation of Brassica napus immunity-related mitogen-activated protein kinases MAPKs. A. Schematic representation of MAPKs activation through chitin-triggered immunity after chitin recognition by plant receptors. B. Western blot (WB) analysis of $B$. napus seedlings after treatment with $1 \mu \mathrm{M}$ chitin (GlcNAc)6 with or without $10 \mu \mathrm{M} P b \mathrm{ChB} 2$ or $\mathrm{PbChB} 4$. PS stand for ponceau stained blots showing the RuBisCO large subunit as protein loading control. Control were treated with water only (mock), $P b C h B 2$ only or $P b C h B 4$ only. Created with BioRender.com.

\section{DISCUSSION}

Historically, chitin-binding effectors have been widely characterized and discovered in fungal plant pathogens (Sánchez-Vallet et al. 2013). We present here the first chitin-binding effectors from a protist, biotrophic soil-borne plant pathogen, the clubroot pathogen. The Brassicas-Plasmodiophora brassicae pathosystem has proven to be very challenging, to the extent that since the discovery of the clubroot disease in the 1700s to this day, only two to four effector proteins have been characterized (Feng et al. 2010; Ludwig-Müller et al. 2015; Yu et al. 2019; Pérez-López et al. 2021). Building on the previous report of CBM18 proteins ( $\mathrm{PbChiBs)-encoding} \mathrm{genes} \mathrm{in} \mathrm{P.} \mathrm{brassicae} \mathrm{genome} \mathrm{(Schwelm} \mathrm{et} \mathrm{al.} \mathrm{2015),}$ we focused on those predicted to be secreted and apoplastic. In this study we found that all three putative apoplastic $\mathrm{PbChiB}$ proteins ( $\mathrm{PbChiB} 1, \mathrm{PbChiB} 2$, and $\mathrm{PbChiB} 4$ ) have a functional signal peptide, suggesting that they might be indeed secreted to the apoplast of the infected plant cell during the infection. 
In this study, we found several CBM18 putative secreted proteins, indicating a possible role of those proteins as effectors. Several of the CBM18 domains found in CE4 proteins might promote efficient substrate deacetylation and transformation to chitosan (Sánchez-Vallet et al. 2015). However, until the activity of the CE4 domain is confirmed, we cannot ascertain the specific role of these proteins. Although we cannot discard the hypothesis that several of them could be strictly involved in pathogen cell wall synthesis and development, several of the families reported here include plant pathogen effectors. For example, MpChi, a Moniliophthora perniciosa effector belonging to the GH18 family, lost its chitinase activity over time, but kept its chitin-binding ability preventing chitin-triggered immunity during the infection (Fiorin et al. 2018), or the Verticillium dahliae polysaccharide deacetylase $V d P D A 1$, an effector that increases the pathogen virulence through the deacetylation of chitin oligomers (Gao et al. 2019).

Here we showed that the expression of the putative secreted chitin-CAZymes was generally host- and life-stage- dependent, evidencing the adaptability of the pathogen and the sole of these proteins during specific life-stages. Similar was observed for $P b C h i B 2$ and $P b C h i B 4$, which transcript was overexpressed during primary infection $(P b C h i B 4)$, and during secondary infection ( $P b C h i B 2$ and $P b C h i B 4)$, more specifically during resting spore development after penetration and during resting spore formation. Taking into account the uniqueness of $P$. brassicae as a plant pathogen, is hard to draw comparison with the expression profile previously reported for other chitin-binding effectors, although something consistent in other studies is the fact that these effectors are overexpressed during biotrophic phases of the infection (Takahara et al. 2016, Volk et al. 2019).

Our results showed that $P$. brassicae effectors $P b C h i B 2$ and $P b C h i B 4$ were able to bind chitin in vitro and to suppress chitin-binding immunity. Similar observations were reported for the $V$. nonalfalfae effector $V n a C h t B P$ during the parasitic life stages of $V$. nonalfalfae and (Volk et al. 2019), In addition, $V n a C h t B P$ was able to prevent hydrolysis of fungal cell walls against plant chitinases, which might explain why the interaction of $P b C h i B 2$ and $P b C h i B 4$ with resting spores was not suppressed by the addition of clubroot infected root xylem sap. Functionally speaking, it seems that the three chitinbinding domains identified in plant pathogens (CBM14, CBM18 and CBM50), have evolved independently towards a similar role in plants (Volk et al. 2019). Unlike VnaChtBP, which has six CBM1 8 modules, $P b C h i B 2$ and $P b C h i B 4$ only have two, similar to the LysM chitin binding effectors ChELP1 and ChELP2 from the anthracnose fungus, C. higginsianum (Takahara et al. 2016). These effectors, although not able to protect fungal hyphae against plant chitinases, supress chitin-binding immunity and are indispensable for appressorial functionality.

Our study highlights the first example of the role of a chitin-binding effector in a plant pathogenic protist, a very understudied evolutionary group. This expands the phenomenon outside of fungal plant pathogens and suggests the evolution of a common strategy among plant pathogens to escape plant immunity. Until very recently, the general belief was that chitin-binding effectors with a single chitinbinding module were not able to suppress chitin-triggered immunity (van Esse et al. 2007; Kohler et al. 2016; Sánchez-Vallet et al. 2013; 2020). The discovery of Mgx 1LysM has challenged this concept by providing evidence that effectors with a single chitin-binding domain were also capable to compete with plant receptors for chitin and suppress immunity (Tian et al. 2020). These findings should support further studies into the $P$. brassicae chitin-binding effectors PbChiB1, which has only one CBM18 module.

Our revised infection model of $P$. brassicae presented in Fig. 6, based on the results obtained in this study, suggests that soon after root penetration, during the transition from spore to primary plasmodium, $P$. brassicae undergoes through changes of the cell wall composition leaving it susceptible to plant chitinases and to the detection of chitin by plant receptor and the subsequent chitintriggered immunity. A similar process occurs during the formation of the resting spores, at a time where 
$P b C h B 2$ and $P b C h B 4$ are highly transcribed. It is interesting that $P b C h B 2$ seems to play a better role 'masking' the spores during the infection, but we believe that the weak suppression of chitin-triggered immunity registered for $\mathrm{PbChB} 4$ might be related with its affinity by chitin, which needs to be further studied. However, we feel confident that we show strong evidence of the important role that $P b C h i B 2$ and $\mathrm{PbChiB} 4$ might be playing 'guarding' and 'masking' P. brassicae.

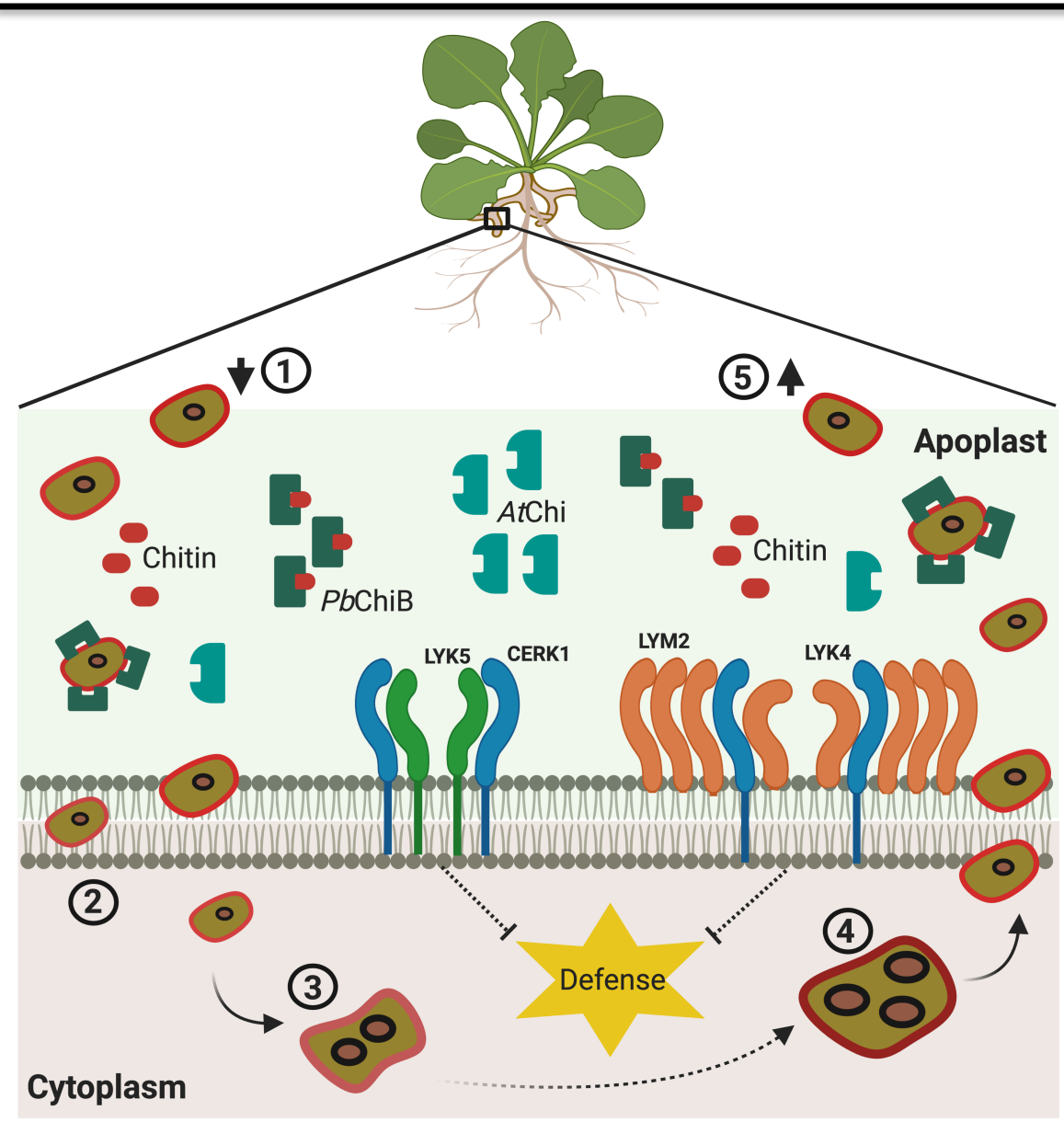

Fig. 6. Schematic representation of how the combined activities of $\mathrm{PbChB} 2$ and $\mathrm{PbChB} 4$ guard and mask $P$. brassicae resting spores during infection. Several steps of $P$. brassicae life cycle are presented: (1) Penetration of the roots by resting spores; (2) penetration of the uninucleated primary plasmodium to the cytoplasm of the infected cell; (3) formation of the multinucleated zoosporangia; (4) Formation of the multinucleated secondary plasmodium; (5) exit of the newly formed resting spores from the infected roots. This is a process that could take place several times in the infected plants until eventually the plant dies dehydrated. The possible role of $P b C h B 2$ and $P b C h B 4$ is presenting as a shield of the resting spores and sequestering chitin in the apoplast. Created with BioRender.com.

\section{AUTHOR CONTRIBUTION}

EPL designed the research; KM and EPL performed the research; KM and EPL analyzed the data; KM and EPL wrote and/or edited the manuscript.

\section{FUNDING}

This work was supported by the start-up funding provided to EPL by the Department of Plant Sciences in the Laval University. 


\section{ACKNOWLEDGES}

Thanks to Prof. Richard Bélanger and Caroline Labbé from CRIV, Université Laval for the support. Thank you also to Prof. Richard Bélanger and Dr. Tim Dumonceaux for the critical review and comments.

\section{REFERENCES}

Asensio, J. L., Cañada, F. J., Siebert, H.-C., Laynez, J., Poveda, A., Nieto, P. M., Soedjanaamadja, U. M., Gabius, H.-J., and Jiménez-Barbero, J. 2000. Structural basis for chitin recognition by defense proteins: GlcNAc residues are bound in a multivalent fashion by extended binding sites in hevein domains. Chem. Biol. 7:529-543.

Andrews, S. 2010. FastQC: A Quality Control Tool for High Throughput Sequence Data [Online]. Available online at: http://www.bioinformatics.babraham.ac.uk/projects/fastqc/

Bolger, A. M., Lohse, M., Usadel, B. 2014. Trimmomatic: a flexible trimmer for Illumina sequence data. Bioinformatics. 30(15):2114-2120.

Burki, F., Kudryavtsev, A., Matz, M. V., Aglyamova, G. V., Bulman, S., Fiers, M., Keeling, P. J., and Pawlowski, J. 2010. Evolution of Rhizaria: new insights from phylogenomic analysis of uncultivated protists. BMC Evol. Biol. 10:377.

Blair, D.E., Schüttelkopf, A.W., MacRae, J.I., and van Aalten, D.M. (2005) Structure and metaldependent mechanism of peptidoglycan deacetylase, a streptococcal virulence factor. Proc Natl Acad Sci U S A. 102, 15429-34.

Chen, W., Li, Y., Yan, R., Xu, L., Ren, L., Liu, F., Zeng, L., Yang, H., Chi, P., Wang, X., Chen, K., Ma, D., and Fang, X. 2019. Identification and characterization of Plasmodiophora brassicae primary infection effector candidates that suppress or induce cell death in host and nonhost plants. Phytopathol. 109(10):1689-1697.

Chevala, C., Samwalda, S., Johnstona, M. G., de Keijzer, J., Breakspear, A., Liua, X., Bellandi, A., Kadota, Y., Zipfel, C. and Faulkner, C. 2020. Chitin perception in plasmodesmata characterizes submembrane immune-signaling specificity in plants. PNAS. 117(17):9621-9629.

Chomczynski, P., and Mackey, K. 1995. Modification of the TRIZOL reagent procedure for isolation of RNA from polysaccharide-and proteoglycan- rich sources. Biotechniques. 19(6):942-945.

de Jonge, R., van Esse, H. P., Kombrink, A., Shinya, T., Desaki, Y., Bours, R., van der Krol, S., Shibuya, N., Joosten, M. H. A. J., and Thomma, B. P. H. J. 2010. Conserved fungal LysM effector Ecp6 prevents chitin- triggered immunity in plants. Science 329:953-955.

Dodds, P. N., and Rathjen, J. P. 2010. Plant immunity: towards an integrated view of plant-pathogen interactions. Nat. Rev. Genet. 11(8):539-548.

Dölfors, F., Holmquist, L., Dixelius, C., and Tzelepis, G. 2019. A LysM effector protein from the basidiomycete Rhizoctonia solani contributes to virulence through suppression of chitin - triggered immunity. Mol. Genet. Genom. 294:1211-1218.

Edgar, R. C. 2004. MUSCLE: a multiple sequence alignment method with reduced time and space complexity. BMC Bioinformatics 5:113.

Feng, J. I. E., Hwang, R. U., Hwang, S. F., Strelkov, S. E., Gossen, B. D., Zhou, Q. X., and Peng, G. 2010. Molecular characterization of a serine protease Pro1 from Plasmodiophora brassicae that stimulates resting spore germination. Mol. Plant Pathol.11:503-512.

Fiorin, G. L., Sanchez-Vallet, A., Thomazella, D. P. De T., do Prado, P. F. V., Do Nascimento, L. D., Figueira, A. V. De O., Thomma, B. P. H. J., Pereira, G. A. G., and Teixeira, P. J. P. L. 2018. Suppression of Plant Immunity by Fungal Chitinase-like Effectors. Current Biol. 28(18):3023-3030. 
Gao, F., Zhang, B.-S., Zhao, J.-H., Huang, J.-F., Jia. P.-S., Wang, S., Zhang, J., Zhou, J.-M., and Guo, H.-S. 2019. Deacetylation of chitin oligomers increases virulence in soil-borne fungal pathogens. Nat. Plants. 5:167-1176.

Goff, L., Trapnell, C., and Kelley, D. 2020. cummeRbund: Analysis, exploration, manipulation, and visualization of Cufflinks high-throughput sequencing data. $\mathrm{R}$ package version 2.32.0.

Jacobs, K. A., Collins-Racie, L. A., Colbert, M., Duckett, M., Golden-Fleet, M., Kelleher, K., Kriz, R., LaVallie, E. R., Merberg, D., Spaulding, V., Stover, J., Williamson, M. J., and McCoy, J. M. 1997. A genetic selection for isolating cDNAs encoding secreted proteins. Gene 198:289-296.

Kehr, J., Buhtz, A., and Giavalisco, P. 2005. Analysis of xylem sap proteins from Brassica napus. BMC Plant Biol. 5: 11.

Kohler, A. C., Chen, L. H., Hurlburt, N., Salvucci, A., Schwessinger, B., Fisher, A. J., Stergiopoulos, I. 2016. Structural analysis of an Avr4 effector ortholog offers insight into chitin binding and recognition by the Cf-4 receptor. Plant Cell 28:1945-1965.

Liu, L., Qin, L., Zhou, Z., Hendriks, W. G. H. M., Liu, S., and Wei, Y. 2020. Refining the Life Cycle of Plasmodiophora brassicae. Phytopathol. 110:1704-1712.

Ludwig-Müller, J., Jülken, S., Geib, K., Richter, F., Mithöfer, A., Šola, I., Rusak, G., Keenan, S., and Bulman, S. 2015. A novel methyltransferase from the intracellular pathogen Plasmodiophora brassicae methylates salicylic acid. Mol. Plant Pathol. 16:349-364.

Marshall, R., Kombrink, A., Motteram, J., Loza-Reyes, E., Lucas, J., Hammond-Kosack, K. E., Thomma, B. P. H. J., and Rudd, J. J. 2011. Analysis of two in planta expressed LysM effector homologs from the fungus Mycosphaerella graminicola reveals novel functional properties and varying contributions to virulence on wheat. Plant Physiol. 156:756-769.

Mentlak, T.A., Kombrink, A., Shinya, T., Ryder, L.S., Otomo, I., Saitoh, H., Terauchi, R., Nishizawa, Y., Shibuya, N., Thomma, B.P., and Talbot, N.J. 2012. Effector-mediated suppression of chitintriggered immunity by magnaporthe oryzae is necessary for rice blast disease. Plant Cell 24:322-335.

Mochizuki, S., Saitoh, K.-I., Minami, E., and Nishizawa, Y. 2011. Localization of probe-accessible chitin and characterization of genes encoding chitin-binding domains during rice-Magnaporthe oryzae interactions. J. Gen. Plant Pathol. 77:163-173.

Pérez-López, E., Hossain, M. M., Tu, J., Waldner, M., Todd, C. D., Kusalik, A. J., Wei, Y., and BonhamSmith, P. C. 2020. Transcriptome analysis identifies Plasmodiophora brassicae secondary infection effector candidates. J. Eukaryot. Microbiol. 67:337-351.

Sánchez-Vallet, A., Mesters, J. R., and Thomma, B. P. H. J. 2015. The battle for chitin recognition in plant-microbe interactions. FEMS Microbiol. Rev. 39:171-183.

Sánchez-Vallet, A., Saleem-Batcha, R., Kombrink, A., Hansen, G., Valkenburg, D.-J. J., Thomma, B. P. H. J., and Mesters, J. R. 2013. Fungal effector Ecp6 outcompetes host immune receptor for chitin binding through intrachain LysM dimerization. eLife 2:e00790.

Sánchez-Vallet, A., Tian, H., Rodriguez- Moreno, L., Valkenburg, D.-J., Saleem-Batcha, R., Wawra, S., Kombrink, A., Verhage, L., de Jonge, R., van Esse, H. P., Zuccaro, A., Croll, D., Mesters J. R., and Thomma, B. P. H. J. 2020. A secreted LysM effector protects fungal hyphae through chitin-dependent homodimer polymerization. PLoS Pathog. 16(6): e1008652.

Saraiva, M., De Brujin, I., Grenville-Briggs, L., Mclaggan, D., Willems, A., Bulone, V., and van West, P. 2014. Functional characterization of a tyrosinase genefrom the oomycete Saprolegnia parasiticaby RNAisilencing. Fungal Biol. 118: 621-629.

Sperschneider, J., Dodds, P. N., Singh, K. B., and Taylor. J. M. 2017. ApoplastP: prediction of effectors and plant proteins in the apoplast using machine learning. New Phytol. 217(4):1764-1778.

Schwelm, A., Fogelqvist, J., Knaust, A., Julke, S., Lilja, T., Bonilla-Rosso, G., Karlsson, M., Shevchenko, A., Dhandapani, V., Choi, S. R., Kim, H. G., Park, J. Y., Lim, Y. P., Ludwig-Muller, J., 
and Dixelius, C. 2015. The Plasmodiophora brassicae genome reveals insights in its life cycle and ancestry of chitin synthases. Sci. Rep., 5:11153.

Takahara, H., Hacquard, S., Kombrink, A., Hughes, H. B., Halder, V., Robin, G. P., Hiruma, K., Neumann, U., Shinya, T., Kombrink, E., Shibuya, N., Thomma, B. P. H. J., and O'Connell, R. J. 2016. Colletotrichum higginsianum extracellular LysM proteins play dual roles in appressorial function and suppression of chitin-triggered plant immunity. New Phytol. 211:1323-1337.

Tamura, K., Stecher, G., Peterson, D., Filipski, A., and Kumar, S. 2013. MEGA6: molecular evolutionary genetics analysis version 6.0. Mol. Biol. Evol. 30:2725-2729.

Tian, H., MacKenzie, C. I. , Rodriguez-Moreno, L., van den Berg, G. C. M., Chen, H., Rudd, J. J., Mesters, J. R., and Thomma, B. P. H. J. 2020. Three LysM effectors of Zymoseptoria tritici collectively disarm chitin-triggered plant immunity. BioRxiv doi: https://doi.org/10.1101/2020.06.24.169789.

Trapnell, C., Williams, B., Pertea, G., Mortazavi, A., Kwan, G., van Baren, M. J., Salzberg, S. L., Wold, B. J., and Pachter, L. 2010. Transcript assembly and quantification by RNA-Seq reveals unannotated transcripts and isoform switching during cell differentiation. Nat. Biotechnol. 28: 511-515.

Tsuda K, Sato M, Stoddard T, Glazebrook J, and Katagiri F. 2009. Network properties of robust immunity in plants. PLoS Genetics 5: e1000772.

van den Burg, H. A., Spronk, C. A. E. M., Boeren, S., Kennedy, M. A., Vissers, J. P. C., Vuister, G. W., de Wit, P. J. G. M., and Vervoort, J. 2004. Binding of the AVR4 elicitor of Cladosporium fulvum to chitotriose units is facilitated by positive allosteric protein-protein interactions: The chitin-binding site of AVR4 represents a novel binding site on the folding scaffold shared between the invertebrate and the plant chitin-binding domain. J. Biol. Chem. 279:16786-16796.

van Esse, H. P., Bolton, M. D., Stergiopoulos, I., de Wit, P. J. G. M., and Thomma, B. P. H. J. 2007. The chitin-binding Cladosporium fulvum effector protein Avr4 is a virulence factor. Mol. PlantMicrobe Interact. 20:1092-1101.

Volk, H., Marton, K., Flajšman, M., Radišek, S., Tian, H., Hein, I., Podlipnik, Č., Thomma, B.P.H.J., Košmelj, K., Javornik, B., and Berne, S. 2019. Chitin-Binding Protein of Verticillium nonalfalfae Disguises Fungus from Plant Chitinases and Suppresses Chitin-Triggered Host Immunity. Mol. PlantMicrob. Interact. 32:1378-1390.

Warton, K., Foster, N.C., Gold, W.A. and Stanley, K.K. 2004. A novel gene family induced by acute inflammation in endothelial cells. Gene 342:85-95.

Yu, F., Wang, S., Zhang, W., Tang, J., Wang, H., Yu, L., Zhang, X., Fei, F., and Li, J. 2019. Genome-wide identification of genes encoding putative secreted E3 ubiquitin ligases and functional characterization of PbRING1 in the biotrophic protist Plasmodiophora brassicae. Curr. Genet. 65:1355-1365.

Zipfel, C. 2014. Plant pattern-recognition receptors. Trends Immunol. 35: 345-351. 


\section{SUPPLEMENTARY TABLE}

Table S1. Primers and plasmids used in this study.

\begin{tabular}{|c|c|c|c|}
\hline $\begin{array}{l}\text { Gene target } \\
\text { (Genbank) }\end{array}$ & Primer name & Used for & Primer sequence $\left(5^{\prime}-3^{\prime}\right) *$ \\
\hline \multirow{4}{*}{$\begin{array}{c}\text { PbChiB2 } \\
(\mathrm{CEP} 01301)\end{array}$} & $P b C h i B 2 q F$ & RT-qPCR & CATTGCAACTGGAGGTCGGA \\
\hline & PbChiB2qR & RT-qPCR & AGTGCACGTTGCAGTGATCG \\
\hline & $P b$ ChiB2spF & $\begin{array}{l}\text { Restriction cloning } \\
\text { into pSUC2 (EcoRI) }\end{array}$ & $\frac{\text { GCGAATTCATGAGCAGCAGC }}{\text { ACCATG }}$ \\
\hline & PbChiB2spR & $\begin{array}{l}\text { Restriction cloning } \\
\text { into pSUC2 (XhoI) }\end{array}$ & $\frac{\text { GCCTCGAGCGCATCGCCCAG }}{\text { GCTCAC }}$ \\
\hline \multirow{4}{*}{$\begin{array}{c}\text { PbChiB4 } \\
(\mathrm{CEP} 03198)\end{array}$} & $P b$ ChiB4qF & RT-qPCR & TAACGCGTGGCAGGGC \\
\hline & $P b$ ChiB4qR & RT-qPCR & TGTTGTTGCAAAACTGCGGG \\
\hline & $P b$ ChiB4spF & $\begin{array}{l}\text { Restriction cloning } \\
\text { into pSUC2 (EcoRI) }\end{array}$ & $\begin{array}{c}\text { GCGAATTCATGAGCAAACTG } \\
\text { GTGAT }\end{array}$ \\
\hline & PbChiB4spR & $\begin{array}{l}\text { Restriction cloning } \\
\text { into pSUC2 (XhoI) }\end{array}$ & $\begin{array}{c}\text { GCCTCGAGCGCAAAGCTCAC } \\
\text { GGTC }\end{array}$ \\
\hline Plasmid & $\begin{array}{l}\text { Backbone } \\
\text { vector }\end{array}$ & $\begin{array}{l}\text { Insert DNA } \\
\text { fragments }\end{array}$ & Cloning strategy \\
\hline $\begin{array}{c}\text { pET- } \\
\text { 14b_PbChiB2 }\end{array}$ & $\mathrm{pET}-14 \mathrm{~b}$ & $\begin{array}{c}\text { Open reading frame } \\
\text { of } P b C h i B 2 \text { lacking } \\
\text { signal peptide }\end{array}$ & $\begin{array}{l}\text { Restriction enzymes (5' XhoI and } \\
\text { 3' BamHI) }\end{array}$ \\
\hline $\begin{array}{c}\text { pET- } \\
\text { 14b_PbChiB4 }\end{array}$ & pET-14b & $\begin{array}{l}\text { Open reading frame } \\
\text { of } P b C h i B 4 \text { lacking } \\
\text { signal peptide }\end{array}$ & $\begin{array}{l}\text { Restriction enzymes ( } 5^{\prime} \text { XhoI and } \\
\text { 3' BamHI) }^{\prime} \text { Bam }\end{array}$ \\
\hline $\begin{array}{l}\text { pSUC2- } \\
P b \text { ChiB2sp }\end{array}$ & pSUC2 & $\begin{array}{c}\text { Open reading frame } \\
\text { of } \mathrm{PbChiB} 2 \text { signal } \\
\text { peptide }\end{array}$ & $\begin{array}{l}\text { Restriction enzymes ( } 5^{\prime} E c o R I \text { and } \\
\left.3^{\prime} X h o \mathrm{I}\right)\end{array}$ \\
\hline $\begin{array}{l}\text { pSUC2- } \\
P b \text { ChiB4sp }\end{array}$ & pSUC2 & $\begin{array}{c}\text { Open reading frame } \\
\text { of } \mathrm{PbChiB} 4 \text { signal } \\
\text { peptide }\end{array}$ & $\begin{array}{l}\text { Restriction enzymes ( } 5^{\prime} E c o R I \text { and } \\
\left.3^{\prime} X h o \mathrm{I}\right)\end{array}$ \\
\hline
\end{tabular}

* Restriction site underlined. 
bioRxiv preprint doi: https://doi.org/10.1101/2020.12.23.423615; this version posted December 24, 2020. The copyright holder for this preprint (which was not certified by peer review) is the author/funder, who has granted bioRxiv a license to display the preprint in perpetuity. It is made available under aCC-BY-NC-ND 4.0 International license.

\section{SUPPLEMENTARY FIGURES}

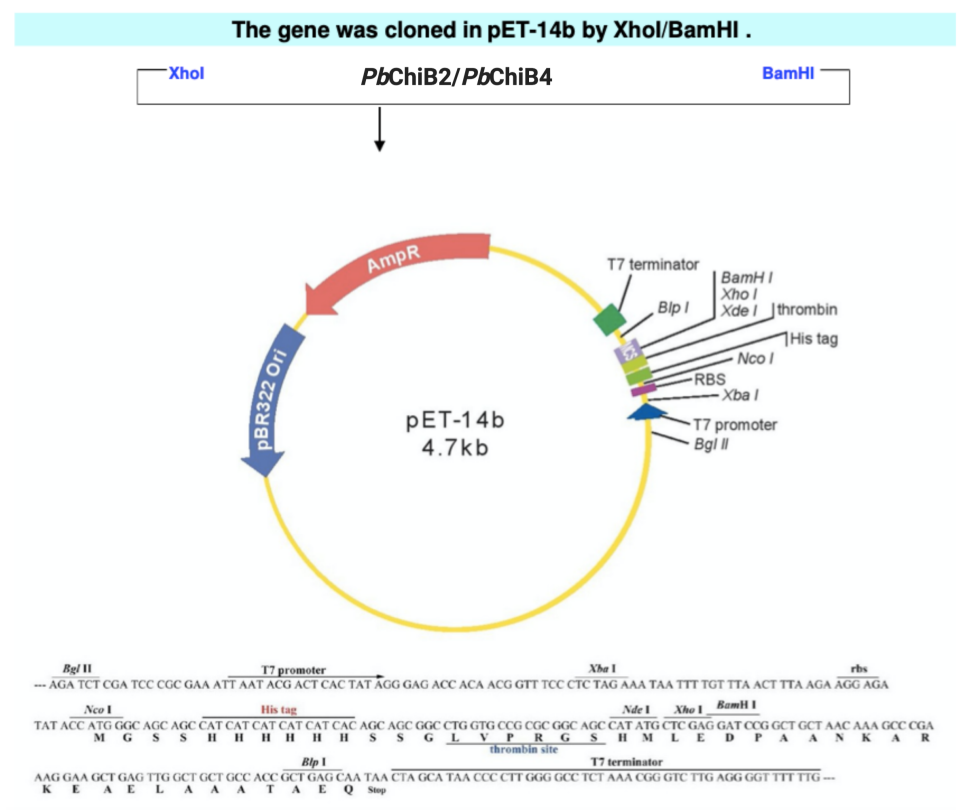

\begin{abstract}
PbChiB2
ATGGAGTGCACGGCGCCGCCGCGGGCGGATGGCCAATGCG GCTATCGCCATGGGAACGCGTCCTGTCTGGTGCCCAACGC GTGTTGCTCCGACTACGGCTGGTGCGGTGTCGATGAGTAC CATTGCAACTGGAGGTCGGAATGTGCCCCGGACATGGCCA AGACGCAATCGATTCCGCAGCCGGCGACGGGGCCATGCCG AACCGCGCCTCGCGACGATATGCGCTGTGGCCCGGATTTC GGCAATGCGGCCTGCCACGCCGCCGGCCAGTGCTGCAGTC AGTACGGCTGGTGCGGATCGGACGCCGATCACTGCAACGT GCACTCGGTGTGCCCTGCGAAGGCCCTGTGA
\end{abstract}

\section{PbChiB4}

ATGCAGATGATTCCGATTAACCCGCCGAACGGCGTGTGGG CGCCGCCGCGCGCGGATAGCCGCTGCGGCCCGGATTTTGG CTGGGCGGGCTGCGGCGATGGCCTGTGCTGCAGCGCGAGC GAATGGTGCGGCAGCGGCCCGATGCATTGCGGCGGCCCGA TGGGCAACTGGGGCCAGGGCGGCGGCAACAACTGGCAGGG CGGCTGGGGCCAGGGCAACAACTGGCAGGGCGATTATAAC GCGTGGCAGGGCGGCTATAACGATTGGCAGGGCGGCTATA ACGATGGCCAGGGCGGCTGGAACGGCAACGGCCAGGGCAT GGGCCCGCCGAACGGCGCGTGGGGCCCGCCGCGCGGCGAT AGCCGCTGCGGCCCGGATTTTGGCTGGGCGGGCTGCGATA GCGGCCAGTGCTGCAGCATGAGCGAATATTGCGGCTATGG CCCGCAGTTTTGCAACAACAACTGGCTGTGA

Fig. S1. Schematic representation of the cloning strategy. Sequence of $P b C h B 2$ and $P b C h B 4$ encoding genes synthesized by Genscript Biotech. Created with BioRender.com.
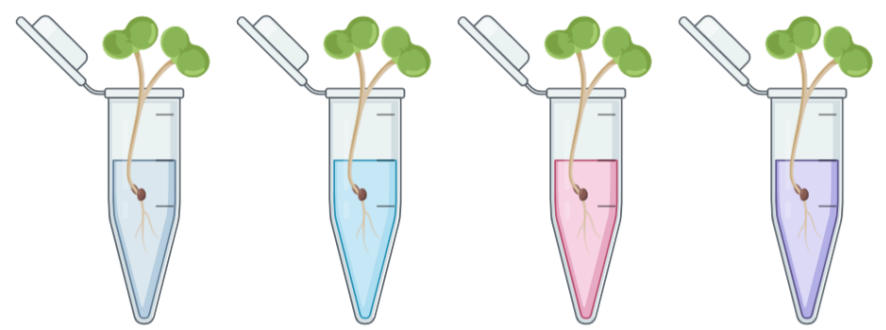

\section{Mock (GlcNAc) 6 PbBChiPs $(\mathrm{GlcNAc})_{6}+\mathrm{PbBChiPs}$}

Fig. S2. Schematic representation of the MAPK activation assay using B. napus seedlings. Three seedlings per treatment were used in each biological replicate of the experiment. Created with BioRender.com. 


\section{PbChiB2 \\ MSSSTMLAIVVLAAAFVSLGDAECTAPPRA DGQCGYRHGNASCLVPNACCSDYGWCGVDE YHCNWRSECAPDMAKTQSIPQPATGPCRTA PRDDMRCGPDFGNAACHAAGQCCSQYGWCG SDADHCNVHSVCPAKAL}

\author{
PbChiB4 \\ MSKLVITVAVVATVSFAQMIPINPPNGVWA \\ PPRADSRCGPDFGWAGCGDGLCCSASEWCG \\ SGPMHCGGPMGNWGQGGGNNWQGGWGQGNN \\ WQGDYNAWQGGYNDWQGGYNDGQGGWNGNG \\ QGMGPPNGAWGPPRGDSRCGPDFGWAGCDS \\ GQCCSMSEYCGYGPQFCNNNWL
}

Fig. S3. Alignment of $P b C h B 1, P b C h B 2$ and $P b C h B 4 C B M 18$ modules. In red cysteine residues and in green conserved serine and aromatic residues associated with the hairpin-loop essential for the chitin-binding activity. In the panels the amino acid sequence of $P b C h B 2$ and $P b C h B 4$. In yellow signal peptide (which was removed in the recombinant proteins), in blue the CBM18-1 and in purple the CBM18-2. To see the CBM18 domain structure please check Prosite PS5094 (https://prosite.expasy.org/doc/PS50941). Created with BioRender.com. 